\title{
TRIVIALIZACIÓN, PREDICADO Y NOMINALIZACIÓN ${ }^{1}$
}

\author{
RAFAEL MIRANDA ROJAS \\ Universidad Católica del Maule, Talca - Chile.
}

\begin{abstract}
RESUMEN: El presente escrito tiene por objetivo discutir los alcances de la denominada vía predicativa en el análisis de la rigidez de los términos generales. En particular, se analizará la interpretación que Zerbudis (2013) realiza de la propuesta desarrollada por Salmon (2005). Se mostrará cómo ambas posturas, en tanto dependen de una lectura predicativa de la rigidez en los términos de clase, no responden al desideratum inicial kripkeano. Siguiendo a López de Sa (2008a, 2008b), se sostiene que la vía nominal (o nominalización) evita los problemas que se derivan de una lectura predicativa reductiva (exigir que los términos generales cumplan sólo el rol de predicado). Específicamente, se sostiene que la vía nominal permite comprender cómo los enunciados de identidad teórica no corren el riesgo de trivialización. A partir del caso el color del cielo, se observa que la exigencia de admisión de identidad contingente (IC) obvia una tesis central de la propuesta kripkeana: la necesidad de la identidad.
\end{abstract}

PALABRAS CLAVE: trivialización; nominalización; vía predicativa; co - referencialidad contingente; co - referencialidad rígida.

\section{Trivialization, predicate and nominalization}

ABSTRACT: The present paper aims to discuss the scope of the rigidity of the general terms through the so-called predicative via. In particular, it will be analized the interpretation of Zerbudis (2013) about the proposal developed by Salmon (2005). It will be shown how both positions, while dependent on a predicative reading of rigidity in general terms, do not respond to the initial kripkean desideratum. Following López de Sa (2008a, 2008b) it argues that the nominal via (or nominalization) avoids the problems arising from a reductive predicative reading (general terms only fulfill the role of predicate). Specifically, it is argued that the nominal reading allows to understand how theoretical statements of identity are not at risk of trivialization. From the case the color of the sky, it is observed that the admission of contingent identity $(\mathrm{Cl})$ obviates a central thesis of Kripke's proposal: the necessity of identity.

KEY WORDS: trivialization; nominalization; predicative via; contingent co - referentiality; rigid co referentiality.

\section{INTRODUCCIÓN}

«there is no point in defining a notion of rigidity for predicates according to which all predicates turn out, trivially, to be rigid» (Soames 2002, 251)

Siguiendo a Åsa Wikforss $(2010,70)$, el problema de la trivialización es propuesto por Soames (2002) como una vía de descarte de rigidez en los términos de clase. Soames enuncia tres condiciones que un término general debiese cumplir para ser entendido como rígido, a saber:

1 La redacción de este escrito se enmarca en el proyecto FONDECYT Iniciación $\mathrm{N}^{\circ}$ 11180422. Mis sinceros agradecimientos por el respaldo. 
«it must be a natural extension of the notion of rigidity defined for singular terms; it must single out the natural kind terms; it must play a role in explaining the necessity of true theoretical identity sentences» (Soames 2002, 263)

De este modo, un término de clase rígido debería ser entendido como un término singular, sin que ello descarte un rol predicativo. Debería, del mismo modo, descartar que otros términos de clase (no naturales) sean rígidos. Y, finalmente, debería explicar cómo los enunciados de identidad teórica son necesariamente verdaderos. Según Soames, estas condiciones no se cumplen conjuntamente y, por lo tanto, la noción de rigidez no es aplicable a los términos generales. Desde que Soames planteó esta crítica, diversos autores han intentado responder desde una vía predicativa a la primera exigencia, rechazando que la segunda exigencia no se cumpla, la ulteriormente denominada trivialización de la rigidez. Recientemente, Zerbudis (2013) analiza esta vía de solución a la trivialización de la rigidez, criticando lo propuesto por Salmon (2005). Sostiene Zerbudis respecto a la primera exigencia enunciada por Soames (2002):

«...it is uncertain whether the notion of rigidity applies to predicative expressions in the first place and, if so, how it should be understood. There is a problem here because, on the one hand, what Kripke defines is not just "rigidity" alone, but "rigid designator", thereby implying that being a designator is a necessary condition for being rigid; but, on the other hand, it is not clear to what extent, and in what sense, predicative expressions could be taken to designate anything.» (Zerbudis 2013, 4)

No sólo Zerbudis releva esta crítica a la posibilidad de que un término general designe, Orlando (2014) sigue la misma línea. Ambos rechazan, por tanto la vía nominativa o, siguiendo a López da Sa (2008a), la nominalización de un término general como vía de solución al rol designativo que cumple un término general. El objetivo central de este escrito es analizar las consecuencias que se siguen de esta vía predicativa en Zerbudis (2013), en particular la consecuencia de que casos de descripciones como «the colour of the sky» sean comprendidas como rígidas. La principal conclusión será que no es una exigencia entender un término general como primaria y principalmente predicativo en vistas a evitar la trivialización de la rigidez en los términos generales.

\section{El (Mismo) COLOR DEL CIELO.}

Rigidez predicativa (predicative rigidity) y designación predicativa (predicative designation) son dos nociones fundamentales en la propuesta desarrollada por Zerbudis en vistas a mostrar cómo descripciones tales como «the colour of the sky» serían rígidas ${ }^{2}$. Ambas nociones exigen, asumen, que el rol predicativo de

2 Siguiendo explícitamente a Sonmes (2002), Zerbudis $(2013,25)$ sostendrá que desde la vía predicativa no hay una aplicación de la noción de rigidez en los términos generales. La vía nominal se descarta, contra el desideratum kripkeano inicial, que se explicitará en el texto principal. 
un término general es su rol principal. Es una tesis intuitivamente correcta, debido a que en el lenguaje cotidiano los términos generales cumplen este rol, el de ser lo que Zerbudis denomina una expresión predicativa (predicative expression):

«I understand by "predicative expression" any kind of expression whose main function consists in ascribing a property (or relation) to one (or more) objects... Moreover, I am taking for granted in this paper that natural kind terms are to be taken as predicative expressions.» (Zerbudis 2013, 4 n. 1)

De este modo, casos como «agua», «oro», «soltero», «rojo», significan o tienen como significado principalmente el predicado «ser agua», "ser oro», «ser soltero», "ser rojo» ¿Qué sostiene Kripke sobre esta comprensión predicativa?

«According to the view I advocate...terms for natural kinds are much closer to proper names than is ordinarily supposed. The old term "common name" is thus quite appropriate for predicates marking out species or natural kinds, such as "cow" or "tiger". My considerations apply also, however, to certain mass terms for natural kinds, such as "gold", "water", and the like.... Perhaps some "general" names ("foolish", "fat", "yellow") express properties. In a significant sense, such general names as "cow" and "tiger" do not, unless being a cow counts trivially as a property. ${ }^{3}$ ( Kripke 1980, 128 - 129)

"Ser una vaca» (being a cow) y « «Vaca» (cow) es un caso paradigmático de lo que Kripke sostiene es una trivialización de un término general ¿Por qué es trivial? Lo que intuye Kripke es que, si un término general cumple el rol nominal, como «vaca», «tigre», «oro», «agua», etc., su rol predicativo se sigue trivialmente. El rol predicativo de ningún modo es descartado, pero si el objetivo es determinar nominalmente la clase, no es el predicado el que cumple ese rol: es el término general entendido como un caso de término referencial. No es una solución la propuesta de designación predicativa, pues es sostener que predicados como «ser vaca» designan el predicado «ser vaca». Por supuesto, así enfrentado el problema, parece que en última instancia el rol principal y

3 Cf. SALmon $(2005,121)$ : «Soames's discussion suffers from a failure to distinguish sharply between a general term like "tiger" and its corresponding predicate, "is a tiger" "No es sorprendente esta cercanía de análisis, considerando que el punto en discusión es cuál es el contenido semántico de términos generales que, prima facie, cumplen un rol distinto del predicativo. Parece correcto sostener que el rol predicativo no reduce la relevancia de esta distinción entre el rol predicativo y el rol designativo. Sobre este punto, es importante destacar cómo Zerbudis $(2013,9)$ atribuye a Salmon la tesis de que en casos como «wise»: «..."wise" by itself apparently only designates the property of being wise». Si este fuese el caso, la distinción que Salmon exige de Soames sería aplicable a su propuesta. Más plausible parece que el autor argentino, al otorgar el rol central al predicado, exige que la nominalización de un predicado tenga el objetivo de sólo designar este mismo predicado. Pero esto es exigir, como Zerbudis (Idem., 8) lo hace, que el término general no sea otra cosa que el predicado: «...an expression should count as a general term if it combines with the "is" of predication to form monadic predicates». Esto descarta la vía nominal, y demanda que los nombres comunes enunciados por Kripke sean trivialmente la expresión designativa de su predicado, lo que parece erróneo. 
el rol secundario es determinado por un sujeto $\mathrm{S}$ y el uso que considere, en un contexto $\mathrm{C}$, principal. Si ese fuese el caso, ambas posturas, la predicativa y la nominal, han obviado algo en el camino. Hay, no obstante, una razón importante para sostener la lectura nominal como principal, y es que evita el problema de la trivialización. Desde la postura predicativa, Zerbudis distingue dos interpretaciones de cómo un término general sería rígido: sameness of designation (semejanza de designación) y essentialist (esencialista):

«sameness of designation ${ }^{4}$ views... according to which a predicative expression is rigid if and only if it designates the same appropriate entity (a property or a kind) in every possible world, and it is non-rigid otherwise... essentialist views, according to which a predicative expression will be considered rigid if and only if it behaves as if it expressed a property that is essential to anything that instantiates it, namely, if and only if, if the expression applies to (or designates) a particular object in some world, it applies to it in every possible world» (Zerbudis 2013, 4-5)

Zerbudis sostiene que la trivialización afecta principalmente a casos de la primera vía, pues una lectura esencialista conduciría a otros problemas (como la exigencia de esencialismo no trivial ${ }^{5}$ ), pero no al de trivialización, salvo que se sostenga una postura híper - esencialista, en cuyo caso el híper - esencialismo sería un caso de trivialización de propiedades esenciales, al ser todas de este tipo. La semejanza de designación predicativa, afirma Zerbudis (2013, 5), no establece una distinción entre casos como:

a) «is blue» - being blue

b) «is a bachelor» - being a bachelor

y

c) «is the colour of the sky» - being of the same colour as the sky.

No lo haría, pues en estos casos: «...the sameness of designation view amounts to the thesis that every predicative expression designates the property which it expresses.» (Ibid.)

Si esto fuese correcto, efectivamente la noción de rigidez tendría una aplicación trivial en los términos generales, afectando la necesidad a posteriori de enunciados como «Agua es $\mathrm{H}_{2} \mathrm{O}$ ", debido a que la vía predicativa no sólo conduce a la admisión predicativa de trivialización, sino a la a prioridad de la determinación de un término general ${ }^{6}$. En a), b) y c) se observa que no se requiere

$4 \quad \mathrm{Al}$ inicio de su escrito, Zerbudis $(2013,3)$ denomina identity of designation across posible worlds a la postura que atribuye a SALMON, pero pronto cambia a sameness of designation (Idem., 4). Si el paso de identidad a (mera) semejanza supone una lectura deflacionaria de un compromiso metafísico, es un punto que no queda del todo establecido. Por ejemplo, Noonan \& CURTIS $(2014,1)$ sostienen que ambos conceptos, identity y sameness, son intercambiables. Sea correcta o no esta lectura, aquí se asume que Zerbudis la comparte, y que same indica identidad y no (mera) semejanza.

5 Cf. Miranda (2016).

6 Cf. Miranda (2014). 
información empírica para determinar el significado de los términos blue, bachelor y colour of the sky, siendo su significado el predicado correspondiente ${ }^{7}$. Esto es resultado de un rechazo explícito a lo que Zerbudis (Ibid.) denomina relación privilegiada (privileged relation), el nexo entre «general terms with nonlinguistic ítems» y cómo esto se observa en la rigidez predicativa vía semejanza de predicación que se obtiene «between a term and the property it expresses» (Ibid.) Es relevante preguntarse porque el enunciado en c) es distinto que en a) y b), o más explícitamente: ¿Por qué no expresar en lugar de

i) being of the same colour as the sky

ii) being the colour of the sky?

No es accidental que se opte por i) y no por ii), que sería el modo análogo de expresar lo que se enuncia en a) y b). Es esta distinción sutil la que conduce a Zerbudis afirmar rigidez en casos como «the colour of the sky». En efecto, la exigencia de mismidad requiere ser explicitada, pues en caso contrario la lectura rígida de casos como "the colour of the sky» no es problemática (prima facie), considerando que la variación de color en cada situación contrafáctica no resta validez a la designación rígida del mismo color, en cada situación contrafáctica. Una tesis intuitiva es que la rigidez puede considerar casos como el color del cielo, desde una lectura reducida (narrow), pero no desde una lectura amplia (wide). Si es el caso que la mismidad exigida por Zerbudis restringe el color del cielo al color actual del cielo (descripción rigidificada), es plausiblemente un caso de rigidez que no amenaza con trivializar la aplicación de esta noción a todo término general. Por ejemplo, la lectura amplia que permite diversos colores como designadores de el color del cielo es descartada como rígida. De cualquier modo, lo más importante en casos de este tipo es que permiten observar ciertas consecuencias implausibles de la vía predicativa, pues en tanto predicados es válida la crítica de cómo establecer la distinción predicado rígido - no rígido, observada por Soames (2002) y Salmon (2005), aunque con diferentes consecuencias en cada caso. Específicamente, afirma Salmon $(2005,123)$, respecto a este caso paradigmático y su aparente lectura rígida:

"Just as the adjective "blue" is a general term...so the definite description "the color of the sky" is a general term...The former rigidly designates the color blue; the latter designates the color non-rigidly.»

Hacia el final de la sección 1 de su escrito, previo al caso «the colour of the sky» discutido directamente por Zerbudis (2013), Salmon $(2005,120)$ afirma que:

"If "bachelor" designates the gendered marital-status category, Unmarried Man, it does so rigidly. Even a common-noun phrase, like "adult male human who is not married", emerges as a rigid designator.»

7 Distinto es sostener que, para evaluar la aplicación de estos predicados en objetos particulares, se requiera de información empírica. 
Es decir, Salmon admite rigidez en casos de lo que él denomina common - noun phrase, cuyo caso paradigmático es bachelor y adult male human who is not married. Pero incluso casos de este tipo no son análogos a the colour of the sky, principalmente porque este segundo caso no corresponde a un common - noun phrase. Así, es la exigencia de mismidad (the same colour as the sky) en relación a la situación actual (SA), en el mundo actual (MA), la tesis implícita en esta lectura de la propuesta realizada por Salmon: un caso de contextualización de la rigidez.

2. Nominalización: LA RELEVANCIA DEL ROL NO PREDICATIVO DE UN TÉRMINO GENERAL

En el inicio de la segunda sección, Salmon $(2005,121)$ observa que una consecuencia de la propuesta realizada por Soames respecto a la trivialización de la rigidez en los términos generales, es la: "demotion of the status of rigidity in Kripke's overall semantic picture” (Soames 2002, 264). Para evitar esta consecuencia, debe explicitarse al menos un caso de término general no rígido, pues en caso contrario la trivialización debiese ser aceptada (al menos de modo falible). Es correcto, tal como sostiene Zerbudis, que el caso propuesto de trivialización es the colour of the sky. La ruta de descarte de trivialización desarrollada por Salmon (2005) puede plantearse del siguiente modo:

a) La noción de rigidez: ¿Es aplicable a términos generales? Respuesta: Sí

b) ¿Todo término general es rígido 8 ? R: No

c) ¿Qué caso (s) permite (n) sostener este rechazo de trivialización? R: Algunas descripciones definidas.

Sobre estas descripciones definidas, sostiene Salmon:

«Definite descriptions are typically singular terms - or alternatively... quantificational expressions that go around impersonating singular terms - but some English definite descriptions, unlike ordinary singular terms, function rather as if they were adjectives or, more likely, mass-noun phrases. One example is the description "the color of the sky", as it occurs in the sentence»

«(P1) My true love's eyesç are the color of the sky.» (Salmon 2005, 122)

Esta cita es particularmente importante, pues permite observar que:

8 Cf. Salmon $(2005,121)$. El autor destaca que el caso de los common count noun (v.gr. tigre. Como se ha mencionado anteriormente, el autor también considera casos como «adult male human who is not married» y su nexo con bachelor) no le compromete con una aplicación trivial de la rigidez en los términos generales: «Even if every common count noun (whether a single word or a phrase) emerges as a rigid designator on my counter-proposal, it does not follow that every general term is rigid.» 
i) no es en tanto descripciones definidas, sino en tanto que funcionan como adjetivos o como una frase nominal de masa (mass - noun phrase), que un término general es no - rígido?.

ii) Salmon propone i) como un modo de descartar una lectura singular de ciertas descripciones definidas en la posición del predicado.

La conclusión que propone Salmon (Idem., 123), a saber:

(C) My true love's eyes are blue.

Permite analizar el rol de la rigidez desde una nueva perspectiva: «blue» es, en $\mathrm{C}$, un término general cumpliendo el rol de adjetivo, de modo rígido; «the color of the sky» es, en P1, un término general, una descripción definida, designando el color no rígidamente ${ }^{10}$ ¿Qué color? ¿Cualquier ${ }^{11}$ color que cumpla la condición de ser el color del cielo)? La pregunta que debe hacerse es si, en este caso, la designación no rígida se debe a que un sujeto $\mathrm{S}$ designa:

i) being of the same colour as the sky

o

ii) being the colour of the sky.

Parece correcto afirmar que es i) y no ii) el criterio que permite afirmar rigidez en casos como the colour of the sky (que sólo designe el color actual en cualquier situación contrafáctica). Se observa también una interpretación predicativa de un término general rígido en Salmon: es el rol de predicado el que está siendo evaluado como rígido o no - rígido. Es relevante enfatizar este punto, pues da lugar a la crítica observada al inicio de este escrito: En tanto predicados ¿Qué diferencia a un término rígido de uno no rígido? Hay diversos aspectos problemáticos de la postura defendida por Salmon, que se siguen de esta vía predicativa. Debe relevarse que no está confundiendo el uso nominal con el predicativo (como él afirma que Soames lo hace con tiger e is a tiger). Pero sí sostiene, explícitamente, que un término general no puede ser comprendido como un término singular:

9 Zerbudis $(2013,11)$ sigue a MAY $(2003)$ en una crítica de este rol adjetival que SALMON enuncia. Si es correcta la crítica, depende en última instancia de cómo se entiende la distinción término singular - frase nominal de masa (mass noun phrase). Lo que sí es claro es cómo Salmon intenta distinguir ambos casos como una vía predicativa de evitar trivialización y, según lo discutido en este escrito, probablemente ese es el punto central: el descarte de la vía nominal como fundamentación de enunciados del tipo "Agua es $\mathrm{H}_{2} \mathrm{O}$ ». Cabe tener presente que este caso de identidad teórica no es análogo al supuesto enunciado de identidad de segundo orden "Blue is the colour of the sky», y ello no descansa, como afirman SaLmon, ZERBUDIS y MAY, en la no - rigidez de the colour of the sky, sino en la no co - referencialidad rígida. Este punto se desarrolla con mayor detalle en el texto principal.

10 Cf. Salmon $(2013,123)$ : «...designates the color non-rigidly.»

11 OrLando $(2014,60)$ observa en el cuantificador whatever (cualquier) una guía de no rigidez. Su ejemplo paradigmático es «the property of being of whatever colour happens to be preferred by Peter» y su nexo con «Peter's favourite colour». Aquí se intenta enfatizar su importancia en contraste con la exigencia de mismidad (same colour as) planteada por ZERBUDIS (2013). 
«Any English term (or English expression that functions as a term when occurring in a predicate) that combines with the "is" of predication to form a monadic predicate, must function as a general term in the predicate so formed. (I take these principles to be partly "criterial" of the distinction between singular and general terms.)»(Salmon 2005, 123)

Y en la nota 12 que acompaña a este texto es aún más explícito en esta postura:

«...linguists and philosophers have argued that a first order definite description following the verb "be" is at least often a general term (or "predicate"), and the copula the "is" of predication rather than the "is" of identity." (Ibid.)

Esto no afectaría los enunciados de identidad teórica ni su status de a posterioridad ( Agua es $\mathrm{H}_{2} \mathrm{O}$ »; "Oro es el elemento cuyo número atómico es $79 »$, etc ${ }^{12}$ ), en tanto dichos enunciados están considerando precisamente la nominalización del término general, y el verbo ser en su uso de identidad. No obstante, exigiría sostener que un término general es un predicado, y que casos como los nombres comunes revisados anteriormente desde Kripke (1980, 128129), al no ser comprendidos predicativamente, no son términos generales. Esto es contraintuitivo, e incluso Salmon considera los casos de los common count noun como rígidos ${ }^{13}$, como casos de términos generales, y como nombres strictu sensu (es decir, no como predicados sino como términos generales que designan, en este caso, una clase C). En otras palabras: términos generales entendidos como designando alguna clase $\mathrm{C}$ son análogos a los términos singulares, no al predicado que determina la extensión de C. Y esta es una vía de solución distinta de la predicativa: es la vía nominal. El descarte de Salmon $(2005,122)$ de la vía nominal en el caso:

(P1) My true love's eyes are the color of the sky.

Se funda en que el uso de «are» no es de identidad, y en el descarte de que un término general se pueda entender como análogo a un término singular:

«Soames sees the definite description in the predicate of (P1) as a singular term rather than a general term. Yet the copula "are" here cannot be the pluralization of the "is" of identity, since the color blue is a single universal whereas the speaker's lover's eyes are two particulars, and hence not both identical to a single thing.» (Ibid.)

12 Cf. Miranda (2012). Allí se cuestiona la vía predicativa, debido a que esta vía abre paso a una crítica de la validez epistémico - metafísica de los enunciados necesarios a posteriori.

13 Esto lo hace líneas después de afirmar la aparente confusión de SoAmEs (2002) entre tiger e is a tiger. SALMON sí considera los nombres comunes contables (common count noun) como rígidos, aun cuando no es del todo claro que sostenga que todo nombre contable (count noun), en tanto contable, es rígido. Sobre este último punto ver SALmon (2015, 124 n.14) dónde sostiene que una descripción de segundo orden puede ser comprendida como nonrigid count-noun. 
¿En qué parte de la oración My true love's eyes are the color of the sky observa Salmon el universal blue? Este supuesto, de que blue y the color of the sky se predican de My true love's eyes es lo que da paso a la crítica de Zerbudis.

3. IDENTIDAD CONTINGENTE, (MERA) CUESTIÓN DE HECHO Y CO REFERENCIALIDAD / CONTINGENTE RÍGIDA

El descarte de rigidez en casos como the colour of the sky lo sostiene Salmon (Idem., 124) a partir de lo que él denomina la premisa empírica (empirical premise), a saber:

«(P2) Blue is the colour of the sky.»

Esta premisa es la que permite establecer el nexo entre

(P1) My true love's eyes are the color of the sky.

$\mathrm{y}$

(C) My true love's eyes are blue.

¿Se debe afirmar que se enuncia una identidad en P2? ¿Es lo que asume Salmon? Esta parece ser la lectura correcta de esa premisa: el que, como (mera) cuestión de hecho, azul es el color del cielo. Es importante analizar este nexo entre lo que se denomina una premisa empírica - (mera) cuestión de hecho. Kripke, en su primera conferencia, explicita que una mera cuestión de hecho corresponde a casos como «(I) Aristotle was fond of dogs» (Kripke 1980, 6):

«Presumably everyone agrees that there is a certain man-the philosopher we call "Aristotle"-such that, as a matter of fact, (I) is true if and only if he was fond of dogs. The thesis of rigid designation is simply...that the same paradigm applies to the truth conditions of (I) as it describes counter/actual situations.» (Ibid.)

Si bien no es un enunciado de identidad, y el uso del verbo ser es predicativo (además de ser un enunciado sobre un objeto singular, y no de una clase C), lo que permite observar este ejemplo es que el nexo premisa empírica - cuestión de hecho no es condición suficiente para establecer co - referencialidad rígida (CRR):

CRR: La exigencia de que los dos términos (específicamente en un enunciado de identidad teórica) no sólo puedan ser comprendidos como rígidos independiente uno de otro ${ }^{14}$ (v.gr. «Héspero» y «Fósforo»), sino de que se determine que designan rígidamente el mismo objeto $\mathrm{O}$ o clase $\mathrm{C}$.

Un ejemplo de co - referencialidad no rígida es el caso renate - cordate $^{15}$. De este modo, es intuitivamente correcto sostener que P2

«Blue is the colour of the sky»

14 Cf. Miranda (2013b). Allí se sostiene que, intuitivamente, la rigidez de casos como «Héspero» y «Fósforo» es determinada de modo independiente. En otras palabras, la rigidez de «Héspero» se establece independiente de su nexo co - referencial rígido.

15 Cf. Fodor (1996). 
expresa co - referencialidad contingente (CRC), como cuestión de hecho, en el mundo actual MA. El punto importante, que es en el que gira la crítica de Zerbudis a Salmon, es el supuesto de que esta premisa empírica exige, para ser comprendida como CRC, que al menos uno de los términos no sea rígido. Sostiene Zerbudis $(2013,6)$ respecto a la premisa «Blue is the colour of the sky» (en la cita, corresponde a A2)

"On the other hand, he (N.A. Salmon) also considers that term to be "manifestly non-rigid"...This gets further support...from the fact that...the (allegedly second order) identity expressed by (A2) is only contingently true (as a result of which at least one of the terms involved in the identity should be non-rigid, "the colour of the sky" being the most obvious candidate) ${ }^{16}$ ”

Como se puede observar con el ejemplo renate - cordate, esto no es completamente correcto, pese a ser la tesis que se acepta usualmente. Si hay una lectura de «the colour of the sky» que permite afirmar rigidez (la lectura narrow, como se ha mencionado anteriormente), no es en toda lectura del enunciado «Blue is the color of the sky» que la CRC se funda en la no rigidez de uno de los términos. Se puede sostener que la CRC, en casos de este tipo, descansa en que:

CRC: Aún si los dos términos son rígidos y designan el mismo objeto $\mathrm{O}$ o clase $\mathrm{C}$ en MA, hay situaciones contrafácticas en las que ambos términos no designan el mismo objeto $\mathrm{O}$ o clase $\mathrm{C}$, aún cuando se puede sostener de modo independiente su rigidez en dichas situaciones contrafácticas.

Esto es: el descarte de CRR.

Parece correcto sostener, en lugar de identidad contingente ${ }^{17}$ en casos de

16 Hacia el final de su escrito, Zerbudis $(2013,20)$ propone la misma estrategia para (en este caso) afirmar que nauseous (asqueado, con náuseas) sea comprendido como rígido en el enunciado $(\mathrm{H})$ What I am is nauseous. El ejemplo es un caso de enunciado de se, lo que permite afirmar al menos rigidez indexical del término yo (lo que Zerbudis descarta). Más importante, Zerbudis afirma que nauseous es rígido porque sólo cumple el rol de predicado: “...'nauseous' can only be construed as a general term." (Ibid.) Finalmente, sostiene que: “... given that I might have been something other than nauseous in the circumstances in which (H) was uttered, which by itself is enough to show that at least one of the two terms appearing in the identity is non-rigid; and, moreover, 'what I am' seems the obvious candidate to be construed as the non-rigid term..." (Ibid.)

17 Cf. Noonan \& CuRTis (2014, 15 sección 7). Si bien los autores sostienen que KRIPKE (1980) no descarta la posibilidad de enunciados de identidad contingentes (en casos que sus términos no sean rígidos), es importante observar que la aplicación del principio de identidad y de diferencia permite sostener plausiblemente que un enunciado de identidad, al ser necesario si es verdadero, no puede ser contingente (pues si es contingente, puede ser falso). En otras palabras, un enunciado de identidad contingente no sería, strictu sensu, un enunciado de identidad. Sobre el nexo entre estos dos principios, sostienen los autores (Ibid.): "...if an object is identical with itself it is necessarily so, and if it is distinct from another it is necessarily so.» Por supuesto, esto no exige aplicación directa a términos de clase, pero parece una tesis intuitivamente correcta que así sea, si se acepta una clase $\mathrm{C}$ como distinta de sus instancias (de su extensión). 
enunciados como "Blue is the colour of the sky", co-referencialidad contingente (CRC). Esto evita un compromiso con la posibilidad de identidades contingentes, un punto que Kripke $(1971,1980)$ rechaza como parte de su postura referencial anti descriptivista ${ }^{18}$. A su vez, la distinción enunciada en la sección I adquiere relevancia, pues "being of the same colour as the sky", en contraste con "being the colour of the sky", permite a Zerbudis una comprensión actualista de esta descripción definida. Proponer el descarte de identidad contingente en casos de este tipo tiene ciertas consecuencias importantes en la crítica de Zerbudis. En particular, el suponer identidad contingente le permite observar un no respeto de la ley de Leibniz, la de sustitución de los idénticos (substitution of equality $\left.{ }^{19}\right)$. Zerbudis $(2013,6)$ aplica esta ley para mostrar la implausibilidad de la argumentación propuesta por Salmon. Conviene enunciarla conjuntamente:

«(A1) My true love's eyes are the colour of the sky.

(A2) Blue is the colour of the sky.

(A3) My true love's eyes are blue.» (Ibid.)

Zerbudis sostiene que (A2) corresponde a un enunciado de identidad contingente (de segundo orden), en lugar de lo que en este escrito se propone como co - referencialidad contingente ${ }^{20}$, sostiene que:

18 Cf. Yagisawa (2014). El autor observa las consecuencias que tiene esta tesis en la comprensión de lo que se entiende por objeto posible. Por su parte, KRIPKE (1971) propone que:

$(\mathrm{x}=\mathrm{y}) \rightarrow(\mathrm{fx} \rightarrow \mathrm{fy})$

se sigue de sostener

$\square(\mathrm{x}=\mathrm{x})$.

Es decir, la necesidad de la identidad. Sobre este punto, ver MiRanda (2009).

19 Cf. Zerbudis $(2013,6-7)$. Noonan \& Curtis $(2014,3)$ plantean una distinción importante en este punto, al afirmar: "Leibniz's Law must be clearly distinguished from the substitutivity principle, that if "a" and " $b$ " are codesignators (if " $a=b$ " is a true sentence of English) they are everywhere substitutable salva veritate.» Esta distinción la consideran los autores, no sólo porque de afirmar $\mathrm{a}=\mathrm{a}$ se exija que se afirme (salva veritate) $\mathrm{a}=\mathrm{b}$, sino porque la ley de Leibniz conduce a la discusión (que Kripke tiene presente) entre identidad númerica e identidad cualitativa. Ese no es el punto central de discusión entre Salmon - ZeRBudis, sino la sustitución de términos co - referenciales no rígidos o, más estrictamente, no designando rígidamente el mismo objeto $\mathrm{O}$ o clase $\mathrm{C}$. Este punto ha sido discutido con más detalle en Miranda (2013b).

20 Cf. Salmon $(2005,124)$ En su propuesta, Salmon asume del mismo modo identidad contingente, y no mera co - referencialidad contingente. Sostiene el autor: «...According to (P2) (N.A. Blue is the color of the sky), the color blue is identical with the color of the sky. Since the speaker's true love's eyes are the color of the sky, it follows by substitution that those same eyes are blue. All you need... is to see the copula in (P2) for what it surely is: an "is" of identity, attached to general terms instead of singular terms, and forming a sentence that is true if and only if the terms flanking the "is" are co-designative.»" Este punto es importante, pues una condición de la distinción entre lo que Salmon denomina (mera) co - designación y co - designación rígida es la exigencia de que la identidad se comprenda como necesaria, pese a que asume que co - designación no rígida corresponde a un caso de identidad contingente. 
«...given that (A3) seems to follow from (A1) and (A2) by Leibniz's Law, it seems reasonable to suppose that the two tokens of "the colour of the sky" appearing there (the one after the "is" of predication in the first premise, the other after the "is" of identity in the second one) are instances of the same type, so that the properties that can be ascribed to that type, given the way in which it appears in one of the premises, can be held to belong to it in all its appearances. ${ }^{21}{ }^{\prime}$

\section{Las consecuencias negativas de esta interpretación son evidentes:}

a) Colour of the sky sería rígido en cualquier lectura predicativa, no sólo la aludida narrow. Esto derivaría en trivialización de la rigidez.

b) Colour of the sky, al tener la propiedad de ser (o ser las propiedades que

${ }^{21}$ Ulteriormente, queda bastante claro que el uso que realiza el autor de la ley de sustitución de los idénticos tiene por objetivo sostener un caso de falacia de equivocación. Hansen $(2015,3)$ siguiendo a Copi (1961), explicita un ejemplo paradigmático de este tipo de falacias:

«The end of life is death.

Happiness is the end of life.

So, death is happiness.»

Puede observarse que la equivocación (o ambigüedad, aunque es una falacia distinta strictu sensu) radica en cómo se entiende end of life en ambas premisas. La intuición de Zerbudis es que puede atribuirse un error similar a Salmon, si éste comprende the colour of the sky como un término singular en una premisa, y como un término general en otra. $\mathrm{O}$, más específicamente, como Blue cumple ese rol de término singular y, al exigirse la sustitución de ambos términos, esto se aplica a the colour of the sky. Zerbudis explicita este punto desde el análisis de Fara (2001) y el ejemplo Max is the man for the job muestra esto de mejor modo:

"I tend to agree that "the man for the job" is used predicatively in this example. But this fact, if it is a fact, has no direct implication concerning the status of "the colour of the sky" in (A1), since the two cases exhibit a significant difference, namely, that, while "the man for the job" does indeed describe Max in the same sense in which "happy" would describe him if we said "Max is happy" (that is, in the sense that its descriptive content is true of him) "the colour of the sky" does not describe my true love's eyes in that same sense» (Zerbudis 2013, 13)

El uso preposicional que ZERBudis toma desde MAY (2003), en el que the colour of the sky es entendido vía predicativa como of the colour of the sky discute el mismo punto. Además, ZERBUDIs (Idem., 15-16) sostiene que este caso de falacia de equivocación ocurre también en su analogía blue-wisdom/wise. Cabe enfatizar que esta argumentación depende del supuesto de identidad contingente:

"...the two positions occupied by "blue" in argument (A) are occupied by two different terms in argument (B)..."wisdom" and "wise", the first of which is an unambiguous name of a virtue and the second of which is an unambiguous adjective ascribing that virtue to somebody, neither of which...could be substituted for the other...it is reasonable to suppose that the two tokens of 'blue' that appear in those two different positions in argument (A) are indeed, either two different (homophonic) words, or two different uses of a single word: in one case what we have is a name for the colour, in the other an adjective ascribing that colour to some particulars.»

Por supuesto, esta propuesta depende de no aceptar que un término general cumpla tanto el rol nominal como el predicativo, que v.gr. blue en tanto predicable de un objeto x sea una instancia de la clase (nominal en este caso) Blue. 
se adscriben a este tipo, siguiendo la cita) My true love's eyes y Blue en las premisas, sería sustituible por estos términos (por la ley de sustitución de los idénticos). Y esto también derivaría en trivialización de la rigidez, pues permitiría sostener no sólo que Colour of the sky es rígido, sino que también My true love's eyes y Blue lo son.

Por supuesto, esto se sigue de

i) asumir identidad contingente en (A2) y de

ii) asumir que la lectura predicativa es la única vía de rigidez de términos generales.

Ambos supuestos, como se ha mostrado, son rechazados por Kripke (1971, 1980). Más allá de esto, Zerbudis quiere mostrar la plausibilidad de su crítica vía analogía, a saber:

«(B1) John has the virtue Socrates was most famous for.

(B2) The virtue Socrates was most famous for is wisdom.

(B3) John is wise.» (Zerbudis 2013, 7)

Pese a que en este caso se apoya en el postulado de significado (meaning postulate) propuesto por Salmon para establecer el nexo semántico wisdom - wise $e^{22}$, es discutible que (B2) sea análogo a (A2). Es decir, aún si se acepta la identidad contingente vía ley de sustitución de los idénticos (lo que ha sido rechazado), el caso de $\mathrm{B} 2$ no parece ser análogo a $\mathrm{A} 2$, principalmente por la inclusión de un término singular (Socrates) ${ }^{23}$. Un análogo podría ser el caso de «Peter's favourite colour», explicitado anteriormente desde Orlando (2014), pero este caso difiere de colour of the sky. Desde una vía nominal, wisdom corresponde a la referencia abstracta de wise: se designa la clase $\mathrm{C}$ en lugar de sus instancias o, en este caso, la propiedad en lugar de sus token específicos. Esta distinción no descarta que wise pueda cumplir, del mismo modo, el rol nominal, y es lo que ocurre en casos de identidad teórica. Blue también cumple este rol, y Zerbudis (Idem., 6) lo observa como una crítica a Salmon desde una comprensión predicativa: el que Blue sea un término singular en A2. Es correcto que términos como blue no son sólo referenciales. Pero Zerbudis $(2013,9-10)$ exige, para comprender como referencial blue, que su único rol sea ése:

«It seems to me...that ordinary language general terms, such as "blue" as it appears in (A3) (N.A. en tanto predicado), are not referential expressions,

\footnotetext{
22 El bi condicional de que «anything is wise iff it has wisdom» (Zerbudis 2013, 7)

23 El que el término singular esté en la posición del predicado es enfatizado ulteriormente por ZERBUDIS $(2013$, 19) como un caso claro de no rigidez predicativa: «...on the most natural way of understanding the problem of general term rigidity, it concerns precisely whether predicative expressions, or terms, not complete predicates containing singular expressions, could be non-rigid (indeed, the latter question could have been solved fairly easily: "... loves the president of the US" would be such a non-rigid predicate)»
} 
that is, they are not expressions whose only semantic task consists in picking out an entity (of whatever kind) as a suitable object of discourse ${ }^{24}$ »

Zerbudis exige, en otras palabras, que un término referencial no cumpla el rol predicativo. Es interesante que, pese a esto, concede a un término predicativo un rol designativo (de sí mismo, subsidiario y secundario): «... what makes a term predicative is that it is used not just to designate an item, but, characteristically, to ascribe it (potentially) to a plurality of other items ${ }^{25}$ » (Idem., 8)

\section{CONCLUSIÓN}

\section{La dicotomía}

i) being of the same colour as the sky

o

ii) being the colour of the sky.

Es considerada por Zerbudis como un caso ad hoc de posible rigidez ${ }^{26}$ que, desde su punto de vista, no altera la principal consecuencia de su análisis: el descarte de rigidez en los términos generales. El principal objetivo de Zerbudis no es mostrar cómo la noción de rigidez tiene aplicación trivial en los términos

24 Cf. SALmon $(2005,123)$. El autor responde a este punto del siguiente modo: «How can a definite description combine with the "is" of predication while designating something? In the same way as he adjective "blue" or the mass noun "water".» El aspecto relevante es que el análisis de Salmon permite comprender el modo cómo un término general cumple el rol como predicado, sin que esto exija el descarte de la rigidez vía nominal, rol que se cumple en los enunciados de identidad teórica. Pese a ello, cabe tener presente lo mencionado en el texto principal: el compromiso de Salmon con identidades contingentes, un punto que resta legitimidad a su propuesta contra la ambigüedad (v.gr. Blue - blue) en los casos de enunciados de identidad teórica.

25 Sólo para explicitar otro lugar en que aparece bastante claro esta oposición asumida, Zerbudis $(2013,13)$ sostiene que afirmar ambos roles sería sostener un dilema: «...the dilemma posed by the prima facie contradictory properties apparently exhibited by "the colour of the sky" (namely, occupying a position requiring a (predicative) general term, but being a (usually referential) singular term itself)» Por supuesto, la precaución de afirmar el criterio prima facie permite anticipar ulteriores interpretaciones como la enunciada aquí. De cualquier modo, considerando lo revisado en el texto principal, parece correcto sostener que esta postura no es meramente prima facie.

26 Cf. Zerbudis $(2013,23)$ El autor da el ejemplo (O) He finally became what he had never been before (sc. happy/ a respected person) como un caso de esta lectura rígida: «The idea would be that "what he had never been before», as it appears in (O), should not be understood as designating, as suggested by the expressions given between brackets, different properties in different circumstances (such as the properties of being happy or of being a respected person), but that, on the contrary, it should be taken as designating, instead, the same property across all possible worlds - in this case, this property rigidly designated would be something like being what $\mathrm{S}$ had never been before t.» 
generales, sino descartar la aplicación de la noción simpliciter. Para ello, acepta tesis opuestas al desideratum inicial kripkeano (y, más importante, de una vía de solución al problema de la trivialización):

a) Descarte de que un término general pueda cumplir el rol nominal y el rol predicativo y, como consecuencia, descarte de rigidez en estos términos;

b) Suposición de identidad contingente como vía de descarte de rigidez. Específicamente, no explicita como criterio débil de este descarte la mera co - referencialidad no rígida. Esta lectura de la ley de sustitución, como se ha observado, exige el rechazo de la necesidad de la identidad (o, en el mejor de los casos, la admisión de la identidad contingente);

c) Asumir que un término general qua término general no puede cumplir el rol nominal. En este punto c) tanto Salmon como Zerbudis se alejan de la tesis inicial kripkeana, en tanto el objetivo de proponer la aplicación de la noción de rigidez a términos generales requiere que sean estos los que, ya en la posición del predicado (vía predicativa), ya en la del sujeto (vía nominal), sean rígidos. Esta solución fuerza a Salmon (2005, 127) a considerar las descripciones en casos nominales como términos singulares de segundo orden (second order singular terms), en lugar de términos generales cumpliendo el rol nominal. En este escrito se ha analizado cómo esto se aleja de la propuesta kripkeana inicial y por ello de una vía de solución al problema de la trivialización de la rigidez; se han enunciado las razones que permiten sostener como plausible la postura kripkeana; y se ha mostrado como en la discusión Salmon - Zerbudis se asume que la lectura rígida debe ser vía predicativa, lo que es rechazado.

\section{BiBLIOGRAFÍA}

Copi, I. M. (1961) Introduction to Logic. (2da ed.). New York: Macmillan.

Fara, D. G. (2001) «Descriptions as Predicates» Philosophical Studies Vol. 102, no. 1. pp. $1-42$

Fodor, J. A. (1996) «Deconstructing Dennett's Darwin» En Mind and Language 11: 246262.

Hansen, H. (2015) «Fallacies». En The Stanford Encyclopedia of Philosophy. Zalta, E. (ed) http://plato.stanford.edu/archives/sum2015/entries/fallacies/

Kripke, S. (1971) «Identity and Necessity» en Munitz, M.K. (ed.) Identity and Individuation. New York: New York University Press. pp. 135-64.

Kripke, S. (1980) Naming and Necessity. Cambridge, MA: Harvard University Press.

López de Sa, D. (2007) «Rigidity, general terms, and trivialization» Proceedings of the Aristotelian Society. pp. 107: 117-23.

López de Sa, D (2008a) «Rigidity for Predicates and the Trivialization Problem» Philosophers Imprint, vol. 8, no. 1, pp. 1-13.

López de Sa, D. (2008b) «The over-generalization problem: predicates rigidly signifying the "unnatural"» Synthese 163. Pp. 263-72.

May, R. (2003) «Comments on Nathan Salmon “Are General Terms Rigid?”» Princeton Semantics Workshop. En http://kleene.ss.uci.edu/ rmay/Salmon.pdf 
Miranda, R. (2009) «Saul Kripke: Necesidad de la identidad y nombres propios» Paralaje $\mathrm{N}^{\circ}$ 2. pp. 143-161.

Miranda, R. (2012a) «Rigidez de jure y de facto en los términos generales para clases naturales». Areté Vol. XXIV No 1. pp. 57-90.

Miranda, R. (2013b) «Enunciados de identidad, invariabilidad proposicional y estipulación contextual» Discusiones Filosóficas Vol. 14, N 23. pp. 105-133.

Miranda, R. (2014) «Bootstrapping y justificación a priori» Discusiones Filosóficas Vol. $15, \mathrm{~N}^{\circ} 25$. pp. 83-94.

Miranda (2016) «Enunciados necesarios a posteriori, necesidad débil y racionalismo» Ideas y Valores, Vol. $65 \mathrm{~N}^{\circ} 160$, abril 2016.

Noonan, H. \& Curtis, B. (2014) «Identity» En The Stanford Encyclopedia of Philosophy. Zalta, E. (ed) http://plato.stanford.edu/entries/identity/

Orlando, E. (2014) «General terms and rigidity: another solution to the trivialization problem» Manuscrito Vol. 37, n. 1. pp. 51-84.

Salmon, N. (2005) «Are general terms rigid?» Linguistics and Philosophy, 28(1), $117-$ 134. Reimpreso desde Content, Cognition, and Communication. Cap. 5. New York. Oxford University Press.

Salmon, N. (2012) «Generality» Philosophical Studies (2012) 161. pp. 471-481 Soames, S. (2002) Beyond Rigidity. The Unfinished Semantic Agenda of Naming and Necessity. Oxford University Press, Oxford.

Soames, S. (2002) Beyond Rigidity, The Unfinished Semantic Agenda of Naming and Necessity. Oxford, Oxford University Press. ix +379 pp.

Wikforss, A. (2010) «Are Natural Kinds Terms Special?» En The Semantics and Metaphysics of Natural Kinds. Beebee, H. \& Sabbarton-Leary, N. (eds.) Routledge, New York. pp. 64-83.

Yagisawa, T. (2014) «Possible Objects» En The Stanford Encyclopedia of Philosophy. Zalta, E. (ed) http://plato.stanford.edu/archives/fall2014/entries/possible-objects/

Zerbudis, E. (2012) «Natural Kinds, Natural Kind Terms, and the Notion of Rigidity», Teorema, vol. 31, no. 2, pp. 171-185.

Zerbudis, E. (2013) «Second Order Descriptions and General Term Rigidity» Critica, vol. 45 , no. 135 , pp. 3-27.

Universidad Católica del Maule, Talca - Chile

Facultad de Ciencias Religiosas y Filosóficas

Rafael Miranda Rojas

Departamento de Filosofía

rafaelmirandarojas@gmail.com

[Aprobado para publicación en diciembre de 2017] 